\title{
PERBEDAAN PREVALENSI PENYAKIT INFEKSI MENULAR SEKSUAL DI INSTALASI RAWAT JALAN RSUD Prof. dr. MARGONO SOEKARJO PERIODE 2010 - 2014
}

\author{
DIFFERENCE OF SEXUALLY TRANSMITTED INFECTIONS \\ PREVALENCES OF THE OUTPATIENTS IN Prof. dr. MARGONO \\ SOEKARJO GENERAL HOSPITAL DURING THE PERIOD 2010 - 2014
}

\author{
Ismiralda Oke Putranti ${ }^{1,2^{*}}$, Citra Primanita ${ }^{2}$, Lilik Karsono ${ }^{2}$, Amelia B. Rahadjo ${ }^{2}$ \\ ${ }^{1}$ Departemen,Ilmu Kesehatan Kulit dan Kelamin, Fakultas Kedokteran Universitas Jenderal Soedirman \\ Jalan dr. Gumbreg No. 1 Mersi Purwokerto, Jawa Tengah, Indonesia \\ ${ }^{2}$ KSM Kesehatan Kulit dan Kelamin RSUD Prof. dr. Margono Soekarjo \\ Purwokerto, Jawa Tengah Indonesia
}

\begin{abstract}
ABSTRAK
Infeksi menular seksual (IMS) saat ini menjadi masalah yang cukup besar selain karena jumlah kasus baru yang masih tinggi, juga karena IMS dapat menimbulkan gejala yang berat, infertilitas dan disabilitas baik pada laki-laki, perempuan maupun bayi. Penelitian ini bertujuan untuk mengetahui perbedaan prevalensi dan karakteristik IMS berdasarkan jenis kelamin di Instalasi Rawat Jalan (IRJ) RSUD Prof dr. Margono Soekarjo pada kurun waktu 2010 - 2014. Penelitian ini merupakan penelitian observasional analitik menggunakan data sekunder rekam medis elektronik. Hasil penelitian didapatkan jumlah kasus IMS di RSUD Prof dr. Margono Soekarjo cukup tinggi, yaitu sebanyak 511 kasus selama kurun waktu 5 tahun penelitian. Pada kasus laki-laki sebanyak 54,9\% dan perempuan sebanyak 45,1\% dengan puncak kejadian pada usia 20 - 30 tahun. Uretritis gonore merupakan penyakit IMS terbanyak pada laki-laki (76,8\%), sedangkan kondiloma akuminata terbanyak pada perempuan $(62,2 \%)$ dan tidak ada perbedaan yang signifikan diantara kedua kelompok jenis kelamin $(p=0,64 ; p>0,05)$. Uretritis gonore dan kondiloma akuminata merupakan penyakit IMS terbanyak pada laki-laki dan perempuan pada penelitian ini, serta tidak adanya perbedaan yang bermakna prevalensi IMS di antara kedua kelompok sesuai dengan penelitian-penelitian sebelumnya yang menyatakan bahwa laki-laki dan perempuan memiliki kerentanan yang sama dalam terpapar IMS. Dari penelitian ini tidak ada perbedaan yang bermakna prevalensi IMS pada pasien laki-laki maupun perempuan di IRJ RSUD Prof dr. Margono Soekarjo.
\end{abstract}

Kata kunci: gonore, infeksi menular seksual (IMS), kondiloma akuminata, usia seksual 


\begin{abstract}
Sexually transmitted infections (STIs) with many new remaining cases still become big issues due to the fact that they may cause severe symptoms, infertility, and disability in both men and women as well as the newborns. The aim of this study was to find out the difference of prevalence and characteristics of the STIs outpatients in Prof. dr. Margono Soekarjo General Hospital during 2010 - 2014 based on genders. This was an analytic observational study based on electronic medical records of the outpatients diagnosed with STIs. In this study, there were 511 outpatients with STIs in the hospital during 5 years of the study, with occurrence in male 54,9\% and female $45,1 \%$. STIs most commonly happen to patient in range of age $20-30$ year with gonorrhea uretritis was the highest case among male patients $(76,8 \%)$ and genital warts (condyloma accuminata) was the highest among female patients $(62,2 \%)$, with ratio of STIs occurrence between male and female patients almost equal with no significant differences ( $p=0,64$ $p>0,05)$. Gonorrhea and genital warts were the most prevalent STIs occurred in both male and female patients and there was no significant difference of the prevalence between the gender groups. This study was consistent with other prior studies which stated that there was no difference between male and female groups in STIs prevalence. The both groups had similar susceptibility of the occurrence of STIs. This study found that there was no significant difference between male and female of STIs outpatients in Prof. dr. Margono Soekarjo general hospital.
\end{abstract}

Keywords: genital warts, gonorrhea, sexually transmitted infections (STIs)

\title{
Correspondence authori:
}

Ismiralda Oke Putranti

Departemen Ilmu Kesehatan Kulit dan Kelamin

Fakultas Kedokteran Universitas Jenderal Soedirman

Jalan dr. Gumbreg No.1 Mersi Purwokerto, Jawa Tengah Indonesia

Email: okkehoes@gmail.com

\section{PENDAHULUAN}

Infeksi menular seksual (IMS) saat ini menjadi masalah utama dunia. IMS dapat menyebabkan gejala klinis yang berat, infertilitas, bahkan disabilitas berkepanjangan sampai kematian dengan konsekuensi medik dan psikologik yang serius baik pada laki-laki, perempuan maupun bayi (WHO, 2012). Infeksi menular seksual umumnya ditularkan melalui hubungan seksual, baik trans-genital, melalui seks oral maupun anal. Selain itu IMS juga dapat ditularkan oleh ibu kepada janinnya saat dalam kandungan maupun pada saat melahirkan, melalui produk darah atau transfer jaringan yang tercemar atau melalui alat-alat kesehatan (WHO, 2013).

Menurut World Health Organization (WHO), prevalensi IMS makin meningkat setiap tahunnya. Pada tahun 2008 diperkirakan terdapat 498,9 juta penderita IMS baru di negara berkembang seperti Afrika, Asia, Asia Tenggara, termasuk Indonesia dan Amerika Latin (WHO, 2012). Di negara-negara dengan prevalensi IMS yang tinggi tersebut ternyata sejalan dengan meningkatnya prevalensi HIV/AIDS. Di Indonesia, uretritis gonore menempati urutan pertama IMS dengan 7,4\% - 50\% dari keseluruhan IMS (Yuwono, 2001). Di propinsi Jawa Tengah jumlah kasus baru IMS pada tahun 2012 sebanyak 8.671 kasus (Dinkes Prop Jateng, 2013). 
Angka kejadian di RSUD Prof. dr. Margono Soekarjo (RSMS) Purwokerto sendiri ternyata dalam kurun 10 tahun terakhir, rerata tercatat 100 - 120 pasien/tahun (SIMRS, 2015). Cukup tingginya angka kejadian IMS di RSMS inilah yang mendorong diperlukannya kajian lebih lanjut mengenai prevalensi dan karakteristik IMS di rumah sakit.

Penelitian ini bertujuan mengetahui perbedaan prevalensi dan karakteristik IMS berdasarkan jenis kelamin di Instalasi Rawat Jalan (IRJ) RSUD RSMS pada kurun waktu 2010 2014.

\section{METODE PENELITIAN}

Penelitian ini menggunakan metode observasional analitik dengan desain penelitian studi belah lintang dimana pengumpulan sampel dengan menggunakan data rekam medis elektronik. Populasi sampel pada penelitian ini adalah seluruh pasien yang menderita IMS yang berobat di RSMS. Populasi terjangkau adalah pasien yang berobat di IRJ RSMS dengan diagnosis IMS pada klinik kulit dan kelamin, klinik kebidanan dan kandungan, klinik bedah urologi dan klinik Voluntary Counseling and Testing (VCT) RSMS periode 2010 - 2014.

Metode pengambilan data menggunakan sampel total, di mana seluruh pasien rawat jalan yang terdiagnosis dengan IMS dari klinik-klinik tersebut diambil sebagai sampel penelitian. Data kemudian dikelompokkan berdasarkan jumlah per tahun kunjungan, jenis kelamin, kategori umur dan jenis-jenis IMS yang disajikan dalam bentuk tabel dan grafik. Data jenis kelamin, kategori usia dan jenis-jenis IMS selanjutnya dilakukan analisis univariat dari masing-masing variabel dan analisis bivariat perbedaan prevalensi IMS berdasarkan jenis kelamin dan kelompok usia menggunakan two-tailed independent t-test.

\section{HASIL DAN PEMBAHASAN}

Berdasarkan data sekunder yang diperoleh dari rekam medis elektronik pasien di instalasi rawat jalan (IRJ) RSMS dengan diagnosis IMS pada periode tahun 2010 - 2014, didapatkan total kunjungan sebesar 511 pasien. Distribusi jumlah pasien IMS per tahun kunjungan dapat dilihat pada gambar 1.

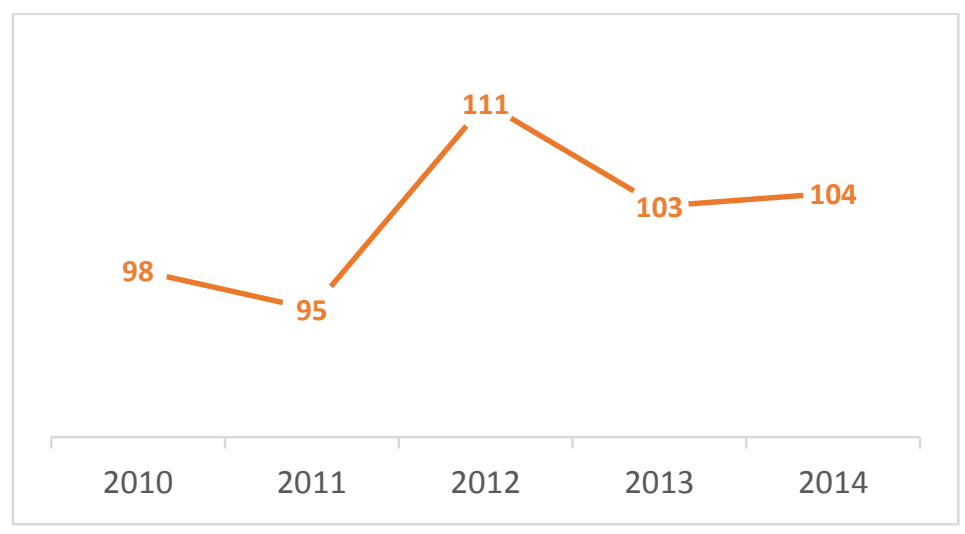

Gambar 1. Distribusi jumlah pasien IMS pada IRJ RSMS periode tahun 2010 - 2014 
Dari keseluruhan 511 pasien IMS periode tahun 2010 - 2014, didapatkan prevalensi berdasarkan jenis kelamin, kelompok usia dan jenis penyakit sebagai berikut ( Tabel I , Gambar 2 dan 3):

Tabel I. Prevalensi Jenis Penyakit IMS Pada IRJ RSMS Tahun 2010 - 2014

\begin{tabular}{|c|c|c|c|c|c|}
\hline \multirow{2}{*}{\multicolumn{2}{|c|}{ Variabel }} & \multicolumn{4}{|c|}{ Jenis Kelamin } \\
\hline & & Laki-laki & $\%$ & Perempuan & $\%$ \\
\hline \multirow{12}{*}{ Kelompok Usia } & $<10$ & 1 & 0.20 & 2 & 0.39 \\
\hline & $11-15$ & 0 & 0.00 & 1 & 0.20 \\
\hline & $16-20$ & 8 & 1.57 & 18 & 3.52 \\
\hline & $21-25$ & 50 & 9.78 & 66 & 12.92 \\
\hline & $26-30$ & 70 & 13.70 & 39 & 7.63 \\
\hline & $31-35$ & 52 & 10.18 & 46 & 9.00 \\
\hline & $36-40$ & 39 & 7.63 & 26 & 5.09 \\
\hline & $41-45$ & 9 & 1.76 & 15 & 2.94 \\
\hline & $46-50$ & 18 & 3.52 & 6 & 1.17 \\
\hline & $51-55$ & 15 & 2.94 & 6 & 1.17 \\
\hline & $56-60$ & 8 & 1.57 & 2 & 0.39 \\
\hline & $>60$ & 11 & 2.15 & 3 & 0.59 \\
\hline \multirow{7}{*}{ Jenis Penyakit } & HIV & 12 & 2.35 & 4 & 0.78 \\
\hline & Granuloma Inguinale & 2 & 0.39 & 2 & 0.39 \\
\hline & Kondiloma akuminata & 43 & 8.41 & 143 & 27.98 \\
\hline & GO & 216 & 42.27 & 60 & 11.74 \\
\hline & Sifilis & 7 & 1.37 & 2 & 0.39 \\
\hline & Lain-lain: Herpes genitalis, Trikomoniasis, Chancroid & 1 & 0.20 & 19 & 3.72 \\
\hline & Jumlah Pasien & 281 & 54.99 & 230 & 45.01 \\
\hline
\end{tabular}

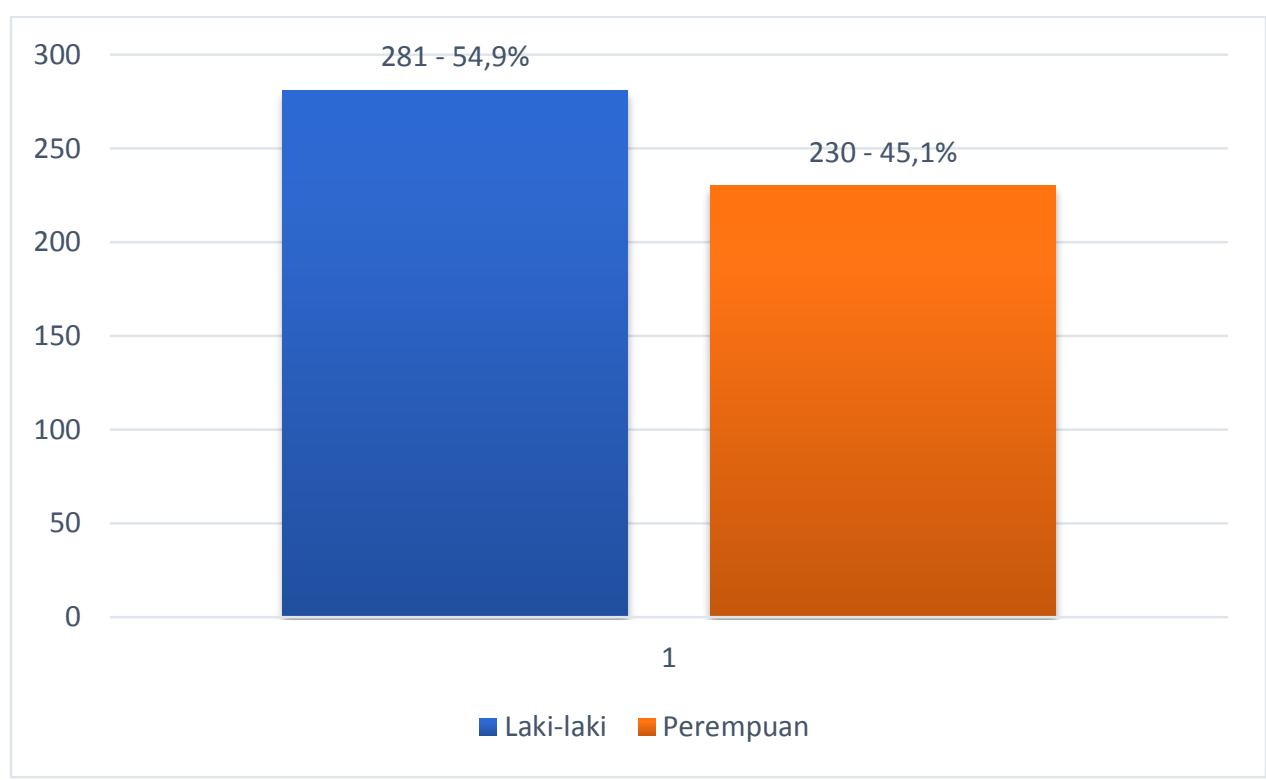

Gambar 2. Prevalensi IMS pada IRJ RSMS periode tahun 2010 - 2014 berdasarkan jenis kelamin 


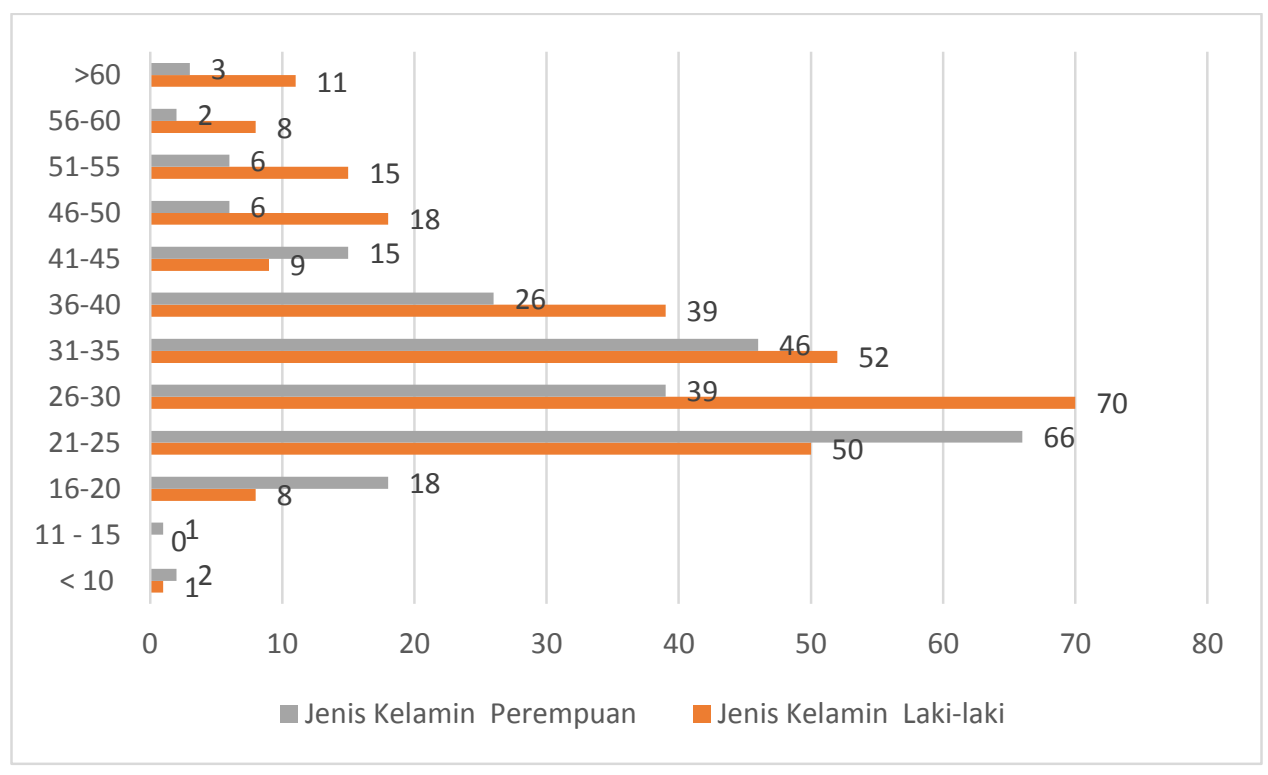

Gambar 3. Prevalensi IMS pada pasien IRJ RSMS periode tahun 2010 - 2014 berdasarkan jenis kelamin dan kelompok usia.

Prevalensi jenis IMS baik pada pasien laki-laki maupun perempuan disajikan dalam gambar berikut (gambar 4)

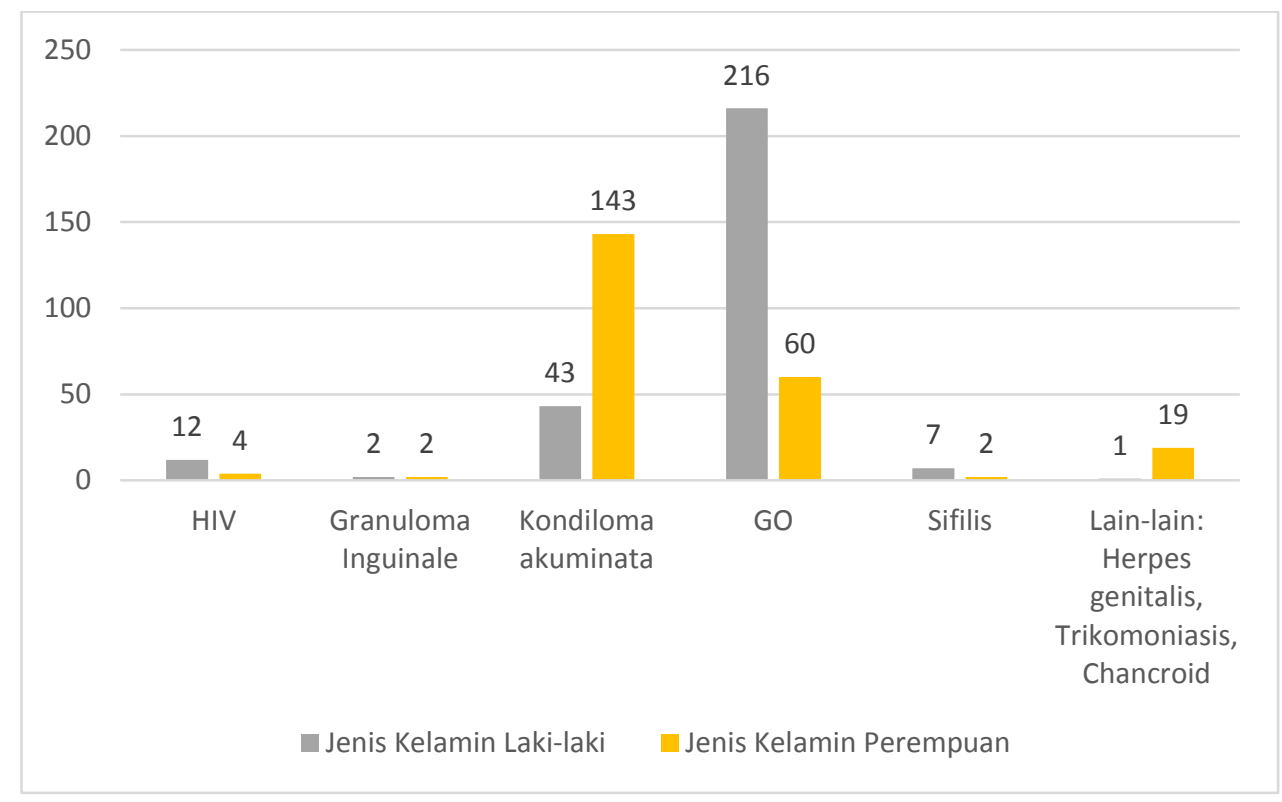

Gambar 4. Prevalensi jenis penyakit IMS di IRJ RSMS periode tahun 2010 - 2014 
Dari data tersebut dilakukan analisis bivariat terhadap perbedaan kelompok usia berdasarkan jenis kelamin dengan menggunakan two-tailed independent $t$-test dan didapatkan hasil sebagai berikut: (Tabel II)

Tabel II. Analisis two-tailed independent $t$-test perbedaan kelompok usia berdasarkan jenis kelamin

\begin{tabular}{cccc}
\hline & Laki-laki & Perempuan & $\boldsymbol{p}$ \\
\cline { 1 - 3 } Rerata & 23.42 & 19.17 & \\
\cline { 1 - 3 } SD & 23.21 & 21.11 & 0,64 \\
\cline { 1 - 3 } SEM & 6.7 & 6.09 & \\
\hline CI 95\% & $\pm 14,74$ & $\pm 13,40$ & \\
\hline N & 12 & 12 & \\
\hline \multicolumn{4}{c}{$p>0,05$ tidak signifikan }
\end{tabular}

Dari hasil penelitian didapatkan pasien IMS yang berkunjung ke IRJ RSMS selama kurun waktu tahun 2010 - 2014 mencapai 511 pasien dengan jumlah pasien laki-laki 281 (54,9\%) dan perempuan $230(45,1 \%)$. Hal ini sesuai seperti halnya penelitian-penelitian lain yang juga menyatakan bahwa laki-laki lebih rentan terkena IMS dibandingkan perempuan meskipun perbedaannya tidak signifikan (Yuwono, 2001). WHO juga menyatakan bahwa IMS pada laki-laki mencapai 266,1 juta (53\%) dari kesuluruhan pasien IMS baru (WHO,2013). Hal senada juga disampaikan oleh Jones (2014), yang menyatakan tradisi dominasi oleh laki-laki dalam hubungan seksual menyebabkan kerentanan terhadap IMS lebih tinggi di samping juga perilaku seksual yang enggan memakai alat pengaman seperti kondom dan lain-lain (Jones, 2014).

Pada penelitian ini juga didapatkan prevalensi tertinggi IMS pada pasien laki-laki terjadi pada kelompok usia 26 - 30 tahun $(13,70 \%$,) sedangkan pada perempuan terbanyak pada kelompok usia 21-25 (12,92\%). Penemuan ini juga sesuai dengan penelitian-penelitian epidemiologi lainnya mengenai IMS yang menyatakan bahwa IMS paling banyak terjadi pada usia 15 - 45 tahun dengan puncak kejadian pada usia seksual aktif 20 - 30 tahun (WHO, 2012; CDC, 2016). Penelitian yang dilakukan oleh Muda (2014) juga menyatakan prevalensi IMS tertinggi terjadi pada rentang usia $26-35$ tahun $(50 \%)$.

Analisis perbedaan prevalensi IMS pada masing-masing jenis kelamin terhadap kelompok usia juga tidak berbeda secara signifikan $(p=0,64 ; p>0,05)$. Tidak adanya perbedaan yang signifikan di antara kedua kelompok jenis kelamin laki-laki dan perempuan juga sejalan dengan penelitian-penelitian sebelumnya yang dilakukan Yuwono (2001) dan Oliffe, et.al. (2013). Hal serupa juga dinyatakan oleh Rosen (2012), di mana sejak tahun 1980 hingga sekarang prevalensi IMS baik pada laki-laki maupun perempuan relatif sama, dan bahkan sedikit lebih tinggi pada perempuan. Prevalensi IMS pada laki-laki terbanyak terjadi pada usia 20-24 tahun, sedangkan pada perempuan pada rentang usia 15-19 tahun (Rosen, 2012).

Jenis penyakit IMS terbanyak pada pasien laki-laki pada penelitian ini adalah uretritis gonore $(42,27 \%)$. Hal ini sesuai dengan penelitian yang dilakukan oleh Yuwono yang menyatakan bahwa uretritis gonore merupakan penyakit IMS terbanyak di Indonesia mencapai 7,4\% - 50\% dari keseluruhan kasus IMS (Yuwono, 2001). WHO pada tahun 2014 juga melaporkan bahwa di 53 negara median kasus uretritis gonore mencapai 25,5 kasus per 100.000 laki-laki dewasa (rentang 0,5-385,5) dan tertinggi dilaporkan terjadi di Pasifik Barat. Berdasarkan data dari Center for Disease Control (CDC) and Prevention Amerika Serikat pada tahun 2015-2016, rerata prevalensi infeksi gonore dilaporkan meningkat mencapai $22,2 \%$ pada laki-laki dan $13,8 \%$ pada perempuan (CDC, 2016). 
Pada penelitian ini prevalensi servisitis gonore menempati urutan kedua (11,74\%), setelah kondiloma akuminata (27,98\%) pada pasien perempuan. Berbeda dengan penelitian yang dilakukan oleh Yuwono (2001) yang menyatakan pada penderita IMS perempuan pun yang terbanyak adalah servisitis gonore (Yuwono, 2001). Hal ini bisa saja terjadi karena infeksi gonore pada perempuan kebanyakan bersifat asimptomatik, sedangkan bila sudah menimbulkan gejala pada umumnya merupakan komplikasi. Berbeda pada laki-laki yang biasanya bersifat simptomatik dengan gejala infeksi yang akut, ditandai dengan keluarnya sekret uretra berwarna putih kekuningan (sekret purulen), 2-8 hari pasca terpapar dengan pasangan seksual yang menderita gonore (Garcia et.al., 2007). Jumlah kasus gonore pada perempuan jumlahnya mungkin dapat sama dengan pasien laki-laki yang berobat jika dilakukan juga pemeriksaan pada pasangan seksual, hanya saja sering kali pasien laki-laki datang berobat sendiri dan menolak memeriksakan pasangan seksualnya (Oliffe, 2013; Jones, 2014). Hasil penelitian berbeda pula dengan yang disampaikan oleh WHO (2016) dan CDC (2016). Kedua lembaga tersebut menyatakan servisitis akibat infeksi Chlamydia menempati urutan pertama kasus IMS pada perempuan (CDC, 2016; WHO, 2016).

Kondiloma akuminata menempati urutan kedua prevalensi IMS di IRJ RSMS pada lakilaki $(8,41 \%)$ dan urutan pertama pada perempuan (27,98\%). Menurut CDC, infeksi human papilloma virus $(H P V)$ merupakan penyakit IMS yang paling sering ditemukan di Amerika Serikat (AS). Prevalensi infeksi genital oleh semua tipe HPV mencapai 42,5\% pada orang dewasa rentang usia 18-59 tahun di AS pada tahun 2013-2014. Infeksi persisten dapat menyebabkan kondiloma akuminata maupun memicu kanker serviks. HPV tipe 6 dan 11 mencapai hampir 90\% sebagai penyebab kondiloma akuminata (CDC, 2016). Sejalan dengan penelitian ini, menurut Wangu dan Burstein (2016), kondiloma akuminata merupakan IMS terbanyak pada wanita, dan pada pengamatan didapatkan $75-80 \%$ individu usia seksual aktif sudah terapapar human papilloma virus $(H P V)$ sebelum berusia 50 tahun (Wangu and Burstein, 2017).

\section{KESIMPULAN}

Prevalensi kejadian Infeksi Menular Seksual (IMS) di IRJ RSUD Prof. dr. Margono Soekarjo Purwokerto pada tahun 2010 - 2014 masih cukup tinggi dengan total 511 kasus dan rerata kejadian 102,2 kasus baru per tahun. Tidak ada perbedaan bermakna prevalensi antara pasien laki-laki dan perempuan hampir dengan puncak kejadian pada usia seksual aktif. Kasus terbanyak baik pada pasien laki-laki maupun perempuan adalah infeksis gonore dan kondiloma akuminata.

\section{UCAPAN TERIMA KASIH}

Penulis mengucapkan terima kasih kepada Rumah Sakit Margono Soekarjo Purwokerto yang terlah memberikan kesempatan untuk melakukan pengambilan data dan melakukan penelitian.

\section{DAFTAR PUSTAKA}

Dinas Kesehatan Provinsi Jawa Tengah. 2013. Buku Profil Kesehatan Provinsi Jawa Tengah tahun 2012. Semarang. Available from http://www.depkes.go.id/resources/download/profil/Profil_Kes_Provinsi_2012/13_Profil _Kes.Prov.JawaTengah_2012.pdf. Diakses 17 Oktober 2015.

Center for Disease Control and Prevention (CDC). 2016. Sexually Transmitted Disease Surveillance 2016. Available online from: 
https://www.cdc.gov/std/stats16/CDC_2016_STDS_Reportfor508WebSep21_2017_1644 .pdf . Diakses 2 Maret 2018.

Garcia, A.L., Madkan, V.K. and Tyring, S.K. 2007. Gonorrhea and other venereal diseases in Wolff, $\mathrm{K}$ et. al. Fitzpatrick's dermatology in general medicine 7th ed. McGraw Hill. New York. 1993-2000.

Jones, T.L. 2014. Gender Beliefs: Susceptibility to Sexually Transmitted Disease. The Wiley Blackwell Encyclopedia of Health, Illness, Behavior, and Society. 594-597.

Muda, F.M. 2014. Faktor-faktor yang berhubungan dengan kejadian infeksi menular seksual pada pasien yang berobat di klinik infeksi menular seksual di Puskesmas Limba B Kecamatan Kota Selatan Kota Gorontalo. Thesis. Universitas Negeri Gorontalo.

Oliffe, J.L. et.al. 2013. Women on men's sexual health and sexually transmitted infection testing: a gender relations analysis. Sociology of Health \& Illness 35(1):1-16.

Rosen, T. 2012. Gonorrhea, Mycoplasma and Vaginosis in Wolff, K et. al. Fitzpatrick's dermatology in general medicine 8th ed. McGraw Hill. New York.2514-2526.

Sistem Informasi Manajemen Rumah Sakit RSUD Prof. dr. Margono Soekarjo. 2015. Purwokerto.

Wangu, Z. and Burstein, G.R. 2017. Adolescent sexuality: updates to the sexually transmitted infection guidelines. Pediatric Clinics of North America 62(2): 389-411.

World Health Organization. 2012. Global incidence and prevalence of selected curable sexually transmitted infections $2008 . \quad$ Geneva. Available from http://apps.who.int/iris/bitstream/10665/75181/1/9789241503839_eng.pdf Diakses 17 Oktober 2015

World Health Organization. 2013. Sexually transmitted infections (STIs). Geneva. Available from http://apps.who.int/iris/bitstream/10665/82207/1/WHO_RHR_13.02_eng.pdf Diakses 17 Oktober 2015

World Health Organization. 2016. Report On Global Sexually Transmitted Infection Surveillance 2015. Geneva. Available online from http://apps.who.int/iris/bitstream/10665/249553/1/9789241565301-eng.pdf?ua=1 Diakses 2 Maret 2018.

Yuwono, D. 2001. Studi resistensi $N$. gonorrhoeae terhadap antimikroba pada wanita pekerja seks di Jawa Barat. Medika Jurnal Kedokteran dan Farmasi, 11: 695-698. 